\title{
The Currency Carry Trade Anomaly
}

\section{Laurence Copeland*}

Department of Finance, Cardiff Business School, UK

For years, currency dealers claimed to be able to earn excess returns from the carry trade i.e. by borrowing in low interest currencies and lending high interest rate currencies. By the end of the last century, the anomaly had been confirmed by a large body of published research, including Fama [1] and many others. The conclusion of this vast literature seemed to be that currencies tended systematically to move in the opposite direction from what was implied by interest rate parity, with high interest rate currencies appreciating and low interest rate currencies depreciating rather than the reverse, a result that was shown to be robust across countries, time periods and variable definitions. In methodological terms, most of the literature involved regression tests of equations like:

$s_{t}-s_{t-1}=a+b\left(f_{t-1}-s_{t-1}\right)+u_{t}$

Where $s_{t}$ is the log of the spot exchange rate, and $f_{t-1}$ the log of the one-month forward rate. The result invariably showed the coefficients $\alpha$ and $b$, which ought to be 0 and 1 respectively, were nothing of the kind. Indeed, the slope coefficient was significantly below 1, often significantly negative. In fact, Burnside et al. [2] quote an average estimate of this key parameter from the published literature of -0.85 !

Is this a free lunch, in clear contravention of efficient market theory and in particular of the interest rate parity theorem?

The most likely explanation for the "excess" return was that it in fact represented the reward for risk. But what were the risk factors?

In recent years, a number of researchers have focused on one or other aspect of the volatility of returns to the carry trade, often using the portfolio approach imported from the stock market literature following the work of Fama and French [3]. Most recently, Menkhoff et al. [4] showed that the return to the carry trade could be well explained by just two factors: a so-called "dollar factor", the simple mean of the return on all currencies against the dollar, and the monthly volatility for each currency (defined as the standard deviation of the previous month's daily returns).

However, it turns out that this explanation can be further unpacked. First, Brunnermeier et al. [5] show that one of the risks which is priced relates to rare events, disasters or crashes in the sense of Barro [6] and the succeeding literature. Second, Copeland and Lu [7] show that on closer inspection almost all the excess return to the carry trade is generated in months when the volatility is low, below its $25^{\text {th }}$ quartile. In months when volatility is highest, in the top quartile, the carry trade generates small positive or indeed negative returns. Hence, the apparent explanatory power of volatility is overwhelmingly a "quiet months" phenomenon. When volatility is high, some other factor drives returns.

Copeland and $\mathrm{Lu}$ [7] go on to show that the other factor is the real exchange rate (see also Nozaki [8]). Recall that the smoothtransition auto regression (STAR) models of e.g. Taylor et al. [9] had already demonstrated that, the further an exchange rate was from its equilibrium level, the more rapidly it would tend to regress in that direction. The implication in terms of volatility was that in the neighbourhood of equilibrium, fluctuations would be small and hence more or less random, so that over- or undervalued currencies would tend to move very little. In this regime, high (low) interest rates would not necessarily tend to depreciate (appreciate), so carry traders would enjoy a return close to the interest rate differential. On the other hand, when exchange rates were relatively far from equilibrium, they would tend to be dragged by the force of purchasing power parity towards their long run real level, imposing losses on carry traders as their long positions in weak high-interest rate currencies fell in value and their short positions in appreciating low interest currencies rose in value.

This literature still has a long way to go before it can be said to have finally resolved the paradox. If the currency markets operate in two different modes depending on whether they are in high- or lowvolatility regimes, what determines the switch between regimes? Is it predictable? And, in any case, why do markets appear to ignore the fundamentals in tranquil periods? Note that this sort of behaviour goes some way to explaining another well-known anomaly, the exchange rate disconnect puzzle. If fundamentals only drive exchange rates in the occasional turbulent months, it is not surprising that models of exchange rate determination fit only poorly when estimated over datasets dominated by long periods of tranquillity.

\section{References}

1. Fama EF (1984) Forward and spot exchange rates. Journal of Monetary Economics 14: 319-338.

2. Burnside R, Eichenbaum M, Kleshchelski I, Rebelo S (2006) The returns to currency speculation. NBER Working Paper No. 12489

3. Fama EF, French KR (1993) Common risk factors in the returns on stocks and bonds. J Financ Econ 33: 3-56.

4. Menkhoff L, Sarno L, Schmeling M, Schrimpf A (2012) Carry trades and global foreign exchange volatility. The Journal of Finance 67: 681-718.

5. Brunnermeier M, Nagel S, Pedersen L (2009) Carry trades and currency crashes, NBER Macroeconomics Annual 2008 23: 313-347.

6. Barro RJ (2006) Rare Disasters and Asset Markets in the Twentieth Century The Quarterly Journal of Economics 121: 823-866.

7. Copeland and Lu (2013) Dodging the Steamroller: Fundamentals versus the Carry Trade. Cardiff Business School, UK.

8. Nozaki M (2010) Do Currency Fundamentals Matter for Currency Speculators? International Monetary Fund.

9. Taylor MP, Peel DA, Sarno L (2001) Nonlinear mean-reversion in real exchange rates: towards a solution to the purchasing power parity puzzles. International Economic Review 42: 1015-1042

*Corresponding author: Laurence Copeland, Department of Finance, Cardiff Business School, UK, Tel: 44-29-20-87574, E-mail: laurence.copeland@ gmail.com

Received February 8, 2014; Accepted February 11, 2014; Published February 14, 2014

Citation: Copeland L (2014) The Currency Carry Trade Anomaly. J Bus Fin Aff 3:e141 doi:10.4172/2167-0234.1000e141

Copyright: (c) 2014 Copeland L. This is an open-access article distributed unde the terms of the Creative Commons Attribution License, which permits unrestricted use, distribution, and reproduction in any medium, provided the original author and source are credited. 